\title{
610 化合物半導体単結晶のインゴットアニール過程における転位密度評価解析 Dislocation Density Analysis of Compound Semiconductor Single Crystal during Ingot Annealing Process
}

\author{
○学 松本 直樹 (京大院) 正 宮崎 則幸 (京大) \\ Naoki MATSUMOTO, Kyoto University, Yoshida-Honmachi, Sakyo-ku, Kyoto, Japan \\ and Noriyuki MIYAZAKI, Kyoto University
}

\section{1. 緒言}

$\mathrm{InP}, \mathrm{GaAs}$ 等の半導体ウェ八製造工程は, 単結晶育成, アニール, ウェ八加工の 3 工程に大別される. その中でア ニールは単結晶の電気特性の改善に不可欠な工程である. しかし，アニール過程において，加熱・冷却時に結晶内部 の温度差により熱応力が発生し,転位が増加してデバイス の性能に悪影響を及ぼすことが予想される。

高温域の固体では, 時間に依存した変形現象であるクリ 一プ現象が顕著になる. 半導体単結晶のクリープ構成式と しては, Haasen-Alexander-Sumino モデル(1)(以降, HAS モ デルと略称する) が知られて抢り,クリープひずみ速度と 転位密度が相互に関連づけられている。

本研究では, 結晶異方性や転位の消滅効果を考慮し,さ らに刃状転位，らせん転位といった転位の種類も考慮に入 れて,より現実に即した転位密度解析プログラムの開発を 行った。 さらに, 開発した解析プログラムを用いて, InP 単結晶のインゴットアニール過程での転位密度評価解析 を行った。

\section{2. 解析方法}

2.1 インゴットアニール解析の概略 まず，アニー ル炬内に置かれた単結晶内部の温度分布の時間変化を, 適 当な解析コードを用いて非定常熱伝導解析を行うことに より求める.このようにして求められた温度分布を入力デ 一タとして用いて, 著者らの研究グループが開発した解析 コードにより,インゴットアニール中の単結晶内部の転位 密度分布とその時間履歴を求める. 解析対象は, 直径 101.6mmのInP単結晶モデルである. 熱伝導解析および転 位密度解析に用いた有限要素モデルをFig.1に示す。両解 析とも3次元の有限要素法によって行った，要素数は 540 , 節点数は2443である. Fig.2に与えた表面温度条件を実線 で, InP単結晶内部の最大温度差の時間履歴を破線で示す。

2.2 転位密度解析 インゴットアニール過程で結晶 内部に生じる温度分布により熱応力が発生し, それにより 既存転位が増殖する可能性がある.このようなアニール過 程における転位密度変化のシミュレーション手法を述べ る.まず,ひずみ速度が次のように分離できると仮定する。

$$
\dot{\varepsilon}_{i j}=\dot{\varepsilon}_{i j}^{e}+\dot{\varepsilon}_{i j}^{i}+\dot{\varepsilon}_{i j}^{c}
$$

上式中の $\dot{\varepsilon}_{i j}, \dot{\varepsilon}_{i j}^{e}, \dot{\varepsilon}_{i j}^{l}, \dot{\varepsilon}_{i j}^{c}$ は, それぞれ全ひずみ速度, 弾性ひ ずみ速度, 熱ひずみ速度, クリープひずみ速度を表すテン ソルである. なお， $\dot{\varepsilon}_{i j}$ は単軸のクリープ挙動を表す $\mathrm{HAS}^{(1)}$ を多軸状態に搪張したものである.

InP GaAs といった f c 単結晶においては, 結晶格子 中に4個のすべり面とそれぞれの面に対して3 個のすべり 方向, すなわち合計 12 個のすべり系が存在する.これら のすべり系での分解せん断応力をテンソル変換の手法を 用いて求めることができる.こうして計算される 12 個の 分解せん断応力がクリープひずみおよび転位増殖の推進 カであると考える。すなわち、

$$
\dot{\varepsilon}_{i j}^{c}=\sum_{n=1}^{12} f^{(n)} P_{i j}^{(n)}
$$

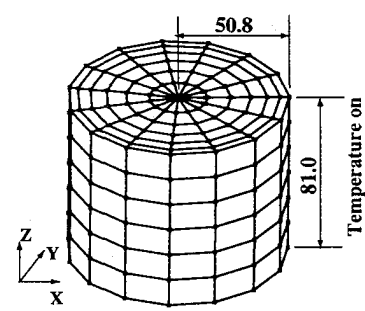
mesh
Fig.1 Finite element

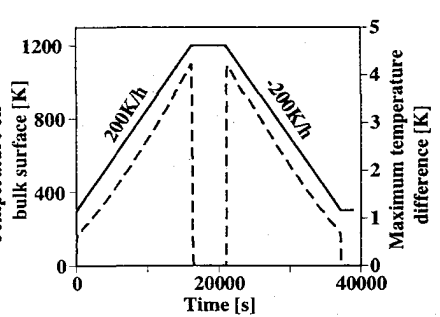

Fig. 2 Temperature on crystal surface and maximum temperature difference

$$
\begin{aligned}
& f^{(n)}=b k_{0} N_{m}\left(\exp \left(\frac{-Q}{k T}\right)\right) \tau_{e f f}^{(n) p} \\
& P_{i j}^{(n)}=\frac{1}{2}\left(\frac{\sigma_{R S}^{(n)}}{\left|\sigma_{R S}^{(n)}\right|}\right)\left(v_{i}^{(n)} b_{j}^{(n)}+v_{j}^{(n)} b_{i}^{(n)}\right) \\
& \tau_{e f f}^{(n)}=\left|\sigma_{R S}^{(n)}\right|-D \sqrt{N_{m}}-\tau_{d}
\end{aligned}
$$

式(2)から(5)において，添字 $(n)$ はすべり系の番号を表し， $\sigma_{R S}^{(n)}$ は分解せん断応力である.また， $P_{i j}^{(n)}$ は Schmid テン ソル， $v_{i}^{(n)}, b_{i}^{(n)}$ はそれぞれすべり面の外向き法線方向およ びすべり方向の単位べクトルである．式(5)は有効せん断 応力であり，值が正のときのみ定義され，クリープひずみ や転位の増殖に寄与すると考える. $D \sqrt{N_{m}}$ は転位同士の 相互作用による転位増殖の抑制効果を表している。 drag stress と呼ばれ, 不純物原子により転位の増殖が妨げ られる効果を表す， $N_{m}$ は動転位密度であるが，大きなひ ずみは生じないので， $N_{m}$ を全転位密度とみなすことがで きる. Table 1 に, HAS モデルに基づく構成式に用いられ るパラメータと InP 単結晶の場合のそれらの值を示す.

すべり系 $n$ の転位の増減速度 $\dot{N}_{m}^{(n)}$ は次式で表される。

$$
\dot{N}_{m}^{(n)}=K k_{0} N_{m}\left(\exp \left(\frac{-Q}{k T}\right)\right) \tau_{\text {eff }}^{(n)}{ }^{p+\lambda}
$$

式(6)に解析時間ステップ $\Delta t$ をかけたものを 1 ステップ前 の時刻のすべり系 $n$ の転位密度 $\left(N_{m}^{(n)}\right)_{t-\Delta t}$ に加えて, 現時刻 のすべり系 $n$ の転位密度を示す. $\left(N_{m}^{(n)}\right)_{t}$ とする. すなわち,

$$
\left(N_{m}^{(n)}\right)_{t}=\left(N_{m}^{(n)}\right)_{t-\Delta t}+\dot{N}_{m}^{(n)} \Delta t
$$

また，全すべり系の転位密度がその時刻での $N_{m}$ である．

$$
N_{m}=\sum_{n=1}^{12}\left|\left(N_{m}^{(n)}\right)_{1}\right|
$$

2.3 クリープ構成式の改良式(6)は転位の消滅効果 は考慮されていない，そこで，転位の消滅効果を考慮した 次の 3 通りの構成式を検討した.

1 つめは, 式(9)の上うに, 転位の増殖速度と転位密度に 符号を持たせる改良である。

$$
\dot{N}_{m}^{(n)}=\left(\frac{\sigma_{R S}^{(n)}}{\left|\sigma_{R S}^{(n)}\right|}\right) K k_{0} N_{m}\left(\exp \left(\frac{-Q}{k T}\right)\right) \tau_{e f f}^{(n)}{ }^{p+\lambda}
$$

〔No.06-9〕日本機械学会第 19 回計算力学講演会講演論文集〔2006-11.3 5 - 名古屋市〕 
Table 1 Parameters in Haasen-Sumino model and their values for InP single crystal

\begin{tabular}{|c|c|c|}
\hline$N_{m}$ & mobile dislocation density & $\mathrm{m}^{-2}$ \\
$Q$ & Peierls potential & $1.0 \mathrm{eV}$ \\
$b$ & magnitude of Burgers vector & $4.2 \times 10^{-10} \mathrm{~m}$ \\
$k$ & Boltzmann's constant & $8.617 \times 10^{-5} \mathrm{eV} / \mathrm{K}$ \\
$T$ & absolute temperature & $\mathrm{K}$ \\
$K$ & material constant & $1.2 \times 10^{-2} \mathrm{~m} / \mathrm{N}$ \\
$D$ & strain hardening factor & $3.0 \mathrm{~N} / \mathrm{m}$ \\
$k_{0}$ & material constant & $1.36 \times 10^{-8} \mathrm{~m}^{2 \mathrm{p}+1} / \mathrm{N}^{\mathrm{p}} \mathrm{s}$ \\
$\tau_{d}$ & drag stress & $\mathrm{Pa}$ \\
$p$ & material constant & 1.4 \\
$\lambda$ & material constant & 1.0 \\
\hline
\end{tabular}

上式右辺の最初の( )の項によって, 分解せん断応力の向き に応じて転位密度の変化速度に符号を持たせる.変化速度 が正ならば正の向きの転位が, 負ならばその逆向きの負の 転位が増殖すると考える。これをモデル $\mathrm{A}$ と呼称する。

2 つめは，転位の種類を考慮した改良である。式(9)は， 転位密度の変化速度が $N_{m}$ すなわち全すべり系の転位密度 の大きさの和に依存しているので，モデル A は交差す心゙ りが発生して 1 つの転位が他のすべり系に移動し得るら せん転位のみを想定したモデルであると考えることがで きる. 次に，式(10)のような構成式を考える.

$$
\dot{N}_{m}^{(n)}=\left(\frac{\sigma_{R S}^{(n)}}{\left|\sigma_{R S}^{(n)}\right|}\right) K k_{0} \mid N_{m}^{(n)}\left(\exp \left(\frac{-Q}{k T}\right)\right) \tau_{e f f}^{(n) p+\lambda}
$$

この式は，転位密度の変化速度が $\left|N_{m}^{(n)}\right|$ ，すなわちすべり 系 $n$ の転位密度の大きさのみに依存しているので, 交差す ベりが発生せず一つの転位が他のすべり系に移動しない 刃状転位のみを想定したモデルであると考える。このモデ ルをモデル B と呼称する，さらに，実際の転位は，刃状 転位あるいはらせん転位だけであるよりは両者が混在し ていると考えるべきである．そこで，式(9)と式(10)の中間 的なモデルとして, 式(11)を提案し，モデル C と呼称する.

$$
\dot{N}_{m}^{(n)}=\left(\frac{\sigma_{R S}^{(n)}}{\left|\sigma_{R S}^{(n)}\right|}\right) K k_{0} \frac{N_{m}+\left|N_{m}^{(n)}\right|}{2} \exp \left(\frac{-Q}{k T}\right) \tau_{e f f}^{(n)}{ }^{p+\lambda}
$$

3 つめは，式(12)で表されるすべり系どうしの転位の相 互作用を考慮した Gondet モデル(2)の導入である。

$$
\left.\begin{array}{l}
\tau_{e f f}^{(n)}=\left|\sigma_{R S}^{(n)}\right|-D \sqrt{N_{m}^{(n)}}-D^{*} \sum_{k \neq n} \sqrt{N_{m}^{(k)}}, D^{*}=1.5 D \\
\dot{N}_{m}^{(n)}=\dot{N}_{m}^{(n)^{+}}-\dot{N}_{m}^{(n)^{-}} \\
\dot{N}_{m}^{(n)^{+}}=\left(K+K^{*} \sum_{k \neq n} N_{m}^{(k)}\right) k_{0} N_{m}^{(n)}\left(\exp \left(\frac{-Q}{k T}\right)\right) \tau_{e f f}^{(n)}{ }^{p+\lambda} \\
\dot{N}_{m}^{(n)^{-}}=A N_{m}^{(n)^{2}} v^{(n)^{2}}, v^{(n)}=k_{0}\left(\exp \left(\frac{-Q}{k T}\right)\right) \tau_{e f f}^{(n) p}
\end{array}\right\}
$$

定数 $K^{*}, A$ は，いろいろな値を入れて解析してみて, 解析 結果が実験值と比べた上でふさわしいと思われる值を採 用している. また，有効応力 $\tau_{\text {eff }}^{(n)}$ にも相互作用を考慮して いる. Gondet モデルに用いられるパラメータは, InP 単結 晶において次のとおりである。

$$
K^{*}=1 \times 10^{-12} \mathrm{~m}^{3} / \mathrm{N}, A=5 \times 10^{-7} \mathrm{~s}
$$

\section{3. 解析結果および考察}

モデル A, B , C および Gondet モデルの場合について, 最 大転位密度の時間変化の比較を Fig. 3 に示す.モデル A, B, Cでは, 加熱過程終了直後の分解せん断応力の向きがそれ

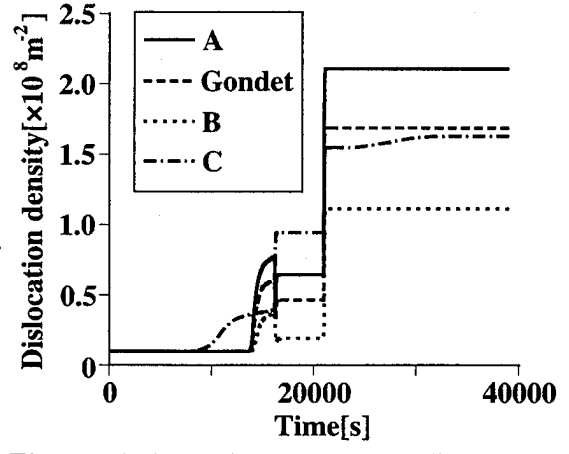

Fig.3 Time variations of the maximum dislocation density (Comparison among model $\mathrm{A}$, model $\mathrm{B}$, model $\mathrm{C}$ and Gondet model)

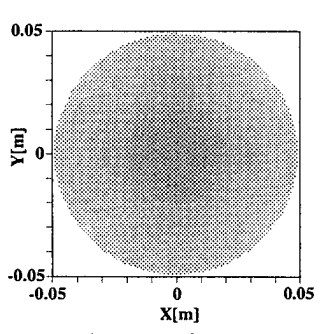

(a) $\mathrm{Z}=2.9 \mathrm{~mm}$

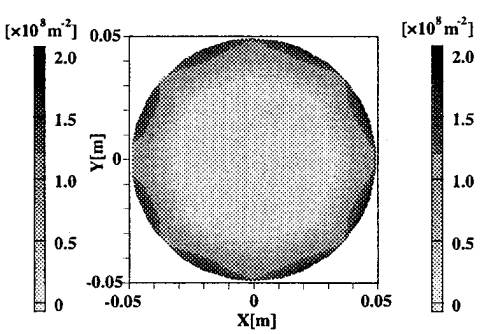

(b) $\mathrm{Z}=43.4 \mathrm{~mm}$
Fig.4 Distributions of dislocation density at cross sections obtained from model C

までの向きと逆方向に生じるために, 転位密度の減少が認 められる。らせん転位のみを考慮したモデル A は, 刃状 転位のみを考慮したモデル B よりも大きな転位密度を与 える. 刃状転位では交差すべりは生じないのが，らせん転 位では交差すべりによって転位がすべり系間を移動し得 るため,より多くの転位増殖源が存在しうると考えられる. モデル A, B の中間的なモデルであるモデル C はモデル A, B のほぼ中間の転位密度を与えていて, アニール過程終了 後の転位密度に関して Gondet モデルに近い結果を与える。 Gondet モデルでは, 転位の消滅速度の式におけるパラメ 一タの值は実験結果に合うように決められているので, こ のモデルは現実に即した結果を与えていると考えられる. Gondet モデルは InP 単結晶の場合にしかパラメータの最 適化は行われていない, 一方, HAS モデルは, 代表的な 半導体単結晶についてそのパラメータが同定されている. HAS モデルを基本としたモデル C が, InP 単結晶について Gondet モデルに近い結果を与えることは, HAS モデルの パラメータが同定されている他の単結晶についてもモデ ルCを用いることができることを示唆している.

モデル C を用いた解析結果として，アニール終了時に おける, 結晶底面から $2.9 \mathrm{~mm}$ (底面付近) と $43.4 \mathrm{~mm}$ (中央付 近)の 2 つの断面における転位密度分布を Fig.4 に示す. 底 面付近では断面中心部で, 中央付近では断面周辺部で転位 密度が大きい，本研究では[001]育成の場合の解析を行っ たため,いずれの断面においても 4 回対称性が確認できる.

\section{4. 結言}

転位の消滅効果を考慮して HAS のクリープ構成式を改 良した。混合転位を想定したモデル C によって，より現 実に即した転位密度解析が行えた。このモデルは InP 単結 晶以外にも, HAS モデルのパラメータが同定されている 他の単結晶についても適用できることが期待される。

\section{参考文献}

(1)K.Sumino, I Yonenaga, Defect Interaction and Clustering in Semiconductors Solid State Phenomena, 85-86 (2002) 145-176 (2)S.Gondet et al, J. Crystal Growth, 252 (2003) 92-101 